International Journal of Current Microbiology and Applied Sciences

ISSN: 2319-7706 Volume 9 Number 1 (2020)

Journal homepage: http://www.ijcmas.com

Original Research Article

https://doi.org/10.20546/ijcmas.2020.901.137

\title{
Effect of Fertigation, Levels on Growth and Yield of Cabbage (Brassica oleracea L. var. capitata)
}

\author{
Mohammadullah Nikzad*, J. S. Aravinda Kumar, M. Anjanappa, \\ H. Amarananjundeswara, B. N. Dhananjaya and G. Basavaraj \\ College of Horticulture, UHS Campus, GKVK, Bengaluru-65, India \\ *Corresponding author
}

\begin{tabular}{|l|}
\hline Ke y w o r d s \\
Fertigation, Growth, \\
Yield, Water \\
Soluble Fertilizers \\
(WSF)
\end{tabular}

Keywords

Fertigation, Growth,

Yield, Water

Soluble Fertilizers

(WSF)

Article Info

Accepted:

Available Online:

20 January 2020

\section{A B S T R A C T}

A field experiment was conducted at Department of Vegetable Science, $\mathrm{CoH}$, GKVK Campus, Bengaluru during Rabi Season of 2018-19 to study the effect of fertigation levels on growth and yield of Cabbage. The experiment was laid out in RCBD with seven treatments replicated thrice. The treatments included three different doses fertilizers (100, 75 and 50\% RDF) and each doses of fertilizers was applied in 12 and 6 equal splits at 5 and 10 days intervals, respectively and they were compared with soil application of 100\% RDF (150: 100: $125 \mathrm{~kg} \mathrm{NPK} \mathrm{ha}^{-1}$ ). Phosphorus was applied as basal dose through soil application whereas Nitrogen and Potassium were applied through fertigation. The result revealed that application of $100 \%$ RDF in 12 equal splits at 5 days intervals significantly recorded maximum plant height $(20.53,30.53$ and $35.46 \mathrm{~cm})$ and plant spread in East-West (59.33, 69.32 and $72.79 \mathrm{~cm})$ and North-South $(59.06,69.06$ and 72.53 $\mathrm{cm})$ directions at 45 DAT, 60 DAT and at harvest, respectively. The same treatment recorded highest individual head weight (1194.23 g), head length (11.60 $\mathrm{cm})$, head diameter $(29.11 \mathrm{~cm})$, head volume $(1296.53 \mathrm{cc})$, head width $(13.60 \mathrm{~cm})$, yield per plot $(33.00 \mathrm{~kg})$ and yield per hectare $\left(43.22 \mathrm{t} \mathrm{ha}^{-1}\right)$.

\section{Introduction}

Cabbage (Brassica oleracea L.var. capitata) is one of the most important cool season vegetable crop belongs to the family Brassicaceae. It is the most popular vegetable around the world with respect to area, production and available, almost round the year. It occupies prime place among cole crops due to its delicious taste, flavour and nutritive value. It is used as salad, boiled vegetable and dehydrated vegetable as well as in cooked curries and pickles. Cabbage is well known for its medicinal properties, it is widely used for cough, fever, diarrhea, peptic ulcers and skin diseases. It has anticancer property due to the presence of indole-3carbinol. It is a rich source of vitamin $\mathrm{C}$ and has high fiber and calcium content which reduces the risk of colon cancer. It also contains phosphorus, which is helpful in utilization of calcium and assimilation of carbohydrates and fats in human body. 
In India, cabbages are grown in an area of $3,99,000$ ha with an annual production of 90,37,000 metric tonnes with an average productivity of $22.65 \mathrm{t} \mathrm{ha}^{-1}$ (Anon., 2018). It is mainly grown in states like Uttar Pradesh, Orissa, Bihar, Assam, West Bengal, Maharashtra and Karnataka. In Karnataka, it is grown in an area of 10,770 ha and an average production of 2,31,210 metric tonnes with an average productivity of $21.47 \mathrm{t} \mathrm{ha}^{-1}$ (Anon., 2016).

Fertigation is reported to enhance the fertilizer use efficiency owing to the frequent application of fertilizers directly into crop root zone and hence, reduction in fertilizer rates is possible without compromising the yield of vegetables. Cabbages are highly responsive to fertilizer application and thus fertilizers offer the best means of increasing yield. Vegetables are perhaps the most intensively irrigated crops all over the world and more so is cabbage. Despite the widespread use of high frequency irrigation system and fertigation elsewhere in India, not much information is available on different aspects of fertigation on closely grown crops like cabbage. Therefore, there is a need to study the vital aspect of fertigation involving the dosage of fertilizers, frequency of fertigation, and methods of fertilizer application. Keeping these points in view, the present study was undertaken to study the "Effect of fertigation levels on growth and yield of cabbage.

\section{Materials and Methods}

A field experiment was conducted at Department of Vegetable Science, College of Horticulture, GKVK Campus, Bengaluru, during Rabi season of 2018-2019, to study the effect of fertigation levels on growth and yield of cabbage. The experimental site is located at $13^{\circ} \mathrm{N}$ latitude and $77.37^{\circ} \mathrm{E}$ longitude in the Eastern Dry Zone of
Karnataka (Zone-5). The altitude of the location is $750 \mathrm{~m}$ above mean sea level. An initial composite soil sample up to a depth of $0-22.5 \mathrm{~cm}$ was collected from the experimental site before imposing treatments. At the end of experiment, treatment wise soil samples were collected from the same depth in undisturbed experimental site. The soil samples were dried under shade, powdered with wooden mallet, passed through $2 \mathrm{~mm}$ sieve and stored in clean polythene bags for analysis. The soil of experimental site was near neutral in reaction $(\mathrm{pH}$ 6.50), low in soluble salts content $\left(0.36 \mathrm{dS} \mathrm{m^{-1 }}\right)$ and medium in available nitrogen $\left(300.60 \mathrm{~kg} \mathrm{ha}^{-}\right.$ ${ }^{1}$ ), phosphorus (40.10 kg ha-1) and potassium (146.49 $\mathrm{kg} \mathrm{ha}^{-1}$ ) content. The experiment was laid in Randomized Complete Block Design (RCBD) with seven treatments replicated thrice. The treatments included the three different doses of fertigation (100, 75 and $50 \% \mathrm{RDF}$ ) and each dose of fertilizers were applied in 12 and 6 equal splits at 5 and 10 days intervals respectively and compared with soil application of 100\% RDF (150: 100: 125 $\mathrm{kg}$ NPK ha ${ }^{-1}$ ). The 100 per cent phosphorus was applied as basal dose through soil application whereas in respect out treatments nitrogen and potassium were applied through fertigation. The spacing of crop was $60 \mathrm{~cm} \times$ $45 \mathrm{~cm}$.

All the recommended cultural practices were followed to maintain good growth of the crop. The observations were recorded on five randomly selected plants in each treatment for twelve characters viz., plant height and plant spread in East-West and North-South directions at 45 DAT, 60 DAT and at harvest, days to first head initiation, days to $50 \%$ head initiation, head weight, head length, head diameter, head volume, head width, yield per plot and yield per hectare. The data were subjected to analysis of variance as per the procedure described by Panse and Sukhatme (1985). 


\section{Results and Discussion}

The results revealed that the plant height significantly varied among the different treatments at 45 DAT, 60 DAT and at harvest (Table 1). The plant height varied from 14.93 $\mathrm{cm}$ to $20.53 \mathrm{~cm}$ at 45 DAT, $24.93 \mathrm{~cm}$ to 30.53 $\mathrm{cm}$ at 60 DAT and $27.20 \mathrm{~cm}$ to $35.46 \mathrm{~cm}$ at harvest. The plant height at different stages of growth was found to be higher with higher doses of fertilizers. The tallest plants were observed when the fertilizers were applied with $100 \%$ RDF (150:100:125 kg NPK ha ${ }^{-1}$ ) in 12 equal splits at 5 days intervals at 45 DAT, 60 DAT and at harvest. On the other hand, shortest plants were observed in soil application of $100 \%$ RDF (14.93, 24.93 and $27.2 \mathrm{~cm}$ at 45 DAT, 60 DAT and at harvest, respectively).

An increased in plant height at $100 \% \mathrm{RDF}$ (150:100:125 kg NPK ha $\left.{ }^{-1}\right)$ in 12 equal splits at 5 days intervals at different stages might be due to maximum uptake of nutrients resulted from better availability of sufficient quantity of major nutrients. The enhanced plant growth might be due to the fact that nitrogen with synthesized carbohydrates was metabolised into amino acids and proteins which allowed the plants to grow faster. As nitrogen is one of the major plant nutrient required for the growth consequently its uptake increases the cell number and size leading to better growth. The results are in conformity with Rakh (1992), Sanchita et al., (2004), Singh et al., (2006), Shinde et al., (2006) and Tanpure et al., (2007).

The plant spread was influenced significantly due to different fertigation levels at all crop growth stages. The plant spread in both EastWest $(59.33,69.32$ and $72.79 \mathrm{~cm})$ and NorthSouth $(59.06,69.06$ and $72.53 \mathrm{~cm})$ directions at 45 DAT, 60 DAT and at harvest was found to be higher with higher doses of fertilizers through fertigation. The plant spread was more when the fertilizers were applied with 100\% RDF (150:100:125 kg NPK ha ${ }^{-1}$ ) in 12 equal splits at 5 days intervals. The minimum plant spread in East-West (52.26, 62.26 and $64.13 \mathrm{~cm})$ and North-South $(52.05,62.00$ and $64.26 \mathrm{~cm}$ ) was noticed due to soil application of $100 \% \mathrm{RDF}$ at $45 \mathrm{DAT}, 60 \mathrm{DAT}$ and at harvest.

The maximum plant spread might be attributed to increased uptake of nutrients and effective utilization of these nutrients for increase synthesis of carbohydrates, greater vegetative growth and subsequent partitioning and translocation from leaf (source) to the head (sink). These results are in conformity with those reported by Rakh (1992), Sanchita et al., (2004), Shinde et al., (2006) and Singh et al., (2004). Overall, the higher doses of NPK fertilizers resulted in higher values of all the growth parameters at different stages of crop growth. The results are in line with those reported by Parameshwara (2003), Hegazi and ALSodon (2001).

The earliness traits like days to first head initiation and fifty per cent head initiation in cabbage were not affected by different levels and methods of fertilizes application in the present study (Table 2). These results are in accordance with those reported by Thompson et al., (2002) and Kadam et al., (2006).

The weight of individual head is an important parameter which ultimately decides the yield of the cabbage crop (Table 2). Fertigation with 100\% RDF (150:100:125 kg NPK ha ${ }^{-1}$ ) in 12 equal splits at 5 days intervals registered significantly higher head weight $(1,194.23 \mathrm{~g})$ than rest of the fertigation levels. Whereas minimum head weight (683.96g) was observed due to Soil application of $100 \%$ RDF. An increased in head weight might be due to increased nutrient availability in the root zone leads greater absorption of nutrients by plants which caused more head weight. 
Table.1 Plant height $(\mathrm{cm})$, plant spread $(\mathrm{cm})$ in North- South and East- West direction at different growth stages of cabbage as influenced by fertigation levels

\begin{tabular}{|c|c|c|c|c|c|c|c|c|c|c|}
\hline \multirow{2}{*}{\multicolumn{2}{|c|}{ Treatments }} & \multirow{2}{*}{\multicolumn{3}{|c|}{ Plant height (cm) }} & \multicolumn{6}{|c|}{ Plant Spread (cm) } \\
\hline & & & & & \multicolumn{3}{|c|}{ North- South direction } & \multicolumn{3}{|c|}{ East- West direction } \\
\hline & & \multirow{2}{*}{$\begin{array}{c}\mathbf{4 5} \\
\text { DAT } \\
19.13\end{array}$} & \multirow{2}{*}{$\begin{array}{c}\text { 60 } \\
\text { DAT } \\
29.13\end{array}$} & \multirow{2}{*}{$\begin{array}{c}\begin{array}{c}\text { At } \\
\text { harvest }\end{array} \\
33.40\end{array}$} & \multirow{2}{*}{$\begin{array}{c}\mathbf{4 5} \\
\text { DAT } \\
58.53\end{array}$} & \multirow{2}{*}{$\begin{array}{c}\text { 60 } \\
\text { DAT } \\
68.59\end{array}$} & \multirow{2}{*}{$\begin{array}{c}\begin{array}{c}\text { Att } \\
\text { harvest }\end{array} \\
70.93\end{array}$} & \multirow{2}{*}{$\begin{array}{c}\mathbf{4 5} \\
\text { DAT } \\
58.59\end{array}$} & \multirow{2}{*}{$\begin{array}{c}\text { 60 } \\
\text { DAT } \\
68.53\end{array}$} & \multirow{2}{*}{$\begin{array}{c}\begin{array}{c}\text { At } \\
\text { harvest }\end{array} \\
70.79\end{array}$} \\
\hline $\mathbf{T}_{1}$ & $\begin{array}{l}\left.100 \% \text { RDF (150:100:125 } \mathrm{kg} \mathrm{NPK} \mathrm{ha}^{-1}\right) \text { in } 6 \text { equal splits at } 10 \\
\text { days intervals }\end{array}$ & & & & & & & & & \\
\hline $\mathbf{T}_{2}$ & $\begin{array}{l}\left.75 \% \text { RDF ( } 112.5: 75: 93.75 \mathrm{~kg} \mathrm{NPK} \mathrm{ha}^{-1}\right) \text { in } 6 \text { equal splits at } \\
10 \text { days intervals }\end{array}$ & 18.53 & 28.53 & 31.33 & 56.52 & 66.53 & 68.13 & 56.25 & 66.26 & 67.79 \\
\hline $\mathbf{T}_{3}$ & $\begin{array}{l}\left.50 \% \text { RDF ( } 75: 50: 62.5 \mathrm{~kg} \mathrm{NPK} \mathrm{ha}^{-1}\right) \text { in } 6 \text { equal splits at } 10 \\
\text { days intervals }\end{array}$ & 16.66 & 26.66 & 29.93 & 53.92 & 63.93 & 65.86 & 54.19 & 64.19 & 66.12 \\
\hline $\mathbf{T}_{4}$ & $\begin{array}{l}\left.100 \% \text { RDF (150:100:125 kg NPK ha }{ }^{-1}\right) \text { in } 12 \text { equal splits at } 5 \\
\text { days intervals }\end{array}$ & 20.53 & 30.53 & 35.46 & 59.06 & 69.06 & 72.53 & 59.33 & 69.32 & 72.79 \\
\hline $\mathbf{T}_{5}$ & $\begin{array}{l}\left.75 \% \text { RDF (112.5:75:93.75 } \mathrm{kg} \mathrm{NPK} \mathrm{ha}^{-1}\right) \text { in } 12 \text { equal splits at } \\
5 \text { days intervals }\end{array}$ & 18.66 & 28.66 & 32.06 & 57.92 & 67.92 & 70.53 & 58.19 & 68.19 & 70.53 \\
\hline $\mathbf{T}_{6}$ & $\begin{array}{l}\left.50 \% \text { RDF ( } 75: 50: 62.5 \mathrm{~kg} \mathrm{NPK} \mathrm{ha}^{-1}\right) \text { in } 12 \text { equal splits at } 5 \\
\text { days intervals }\end{array}$ & 17.80 & 27.80 & 30.26 & 55.13 & 65.13 & 67.06 & 55.06 & 65.06 & 66.79 \\
\hline $\mathbf{T}_{7}$ & Soil application of $100 \%$ RDF (150:100:125 kg NPK ha $\left.{ }^{-1}\right)$ & 14.93 & 24.93 & 27.20 & 52.05 & 62.00 & 64.26 & 52.26 & 62.26 & 64.13 \\
\hline & S.Em \pm & 0.24 & 0.44 & 0.48 & 0.93 & 1.04 & 0.89 & 0.60 & 1.41 & 1.18 \\
\hline & CD@ 5\% & 0.76 & 1.37 & 1.49 & 2.91 & 3.23 & 2.76 & 1.89 & 4.39 & 3.68 \\
\hline
\end{tabular}


Table.2 Days to first and 50 per cent head initiation, fresh head weight $(\mathrm{g})$, head diameter $(\mathrm{cm})$, head volume (cc), head length (cm), head width $(\mathrm{cm})$, and yield of cabbage as influenced by fertigation levels

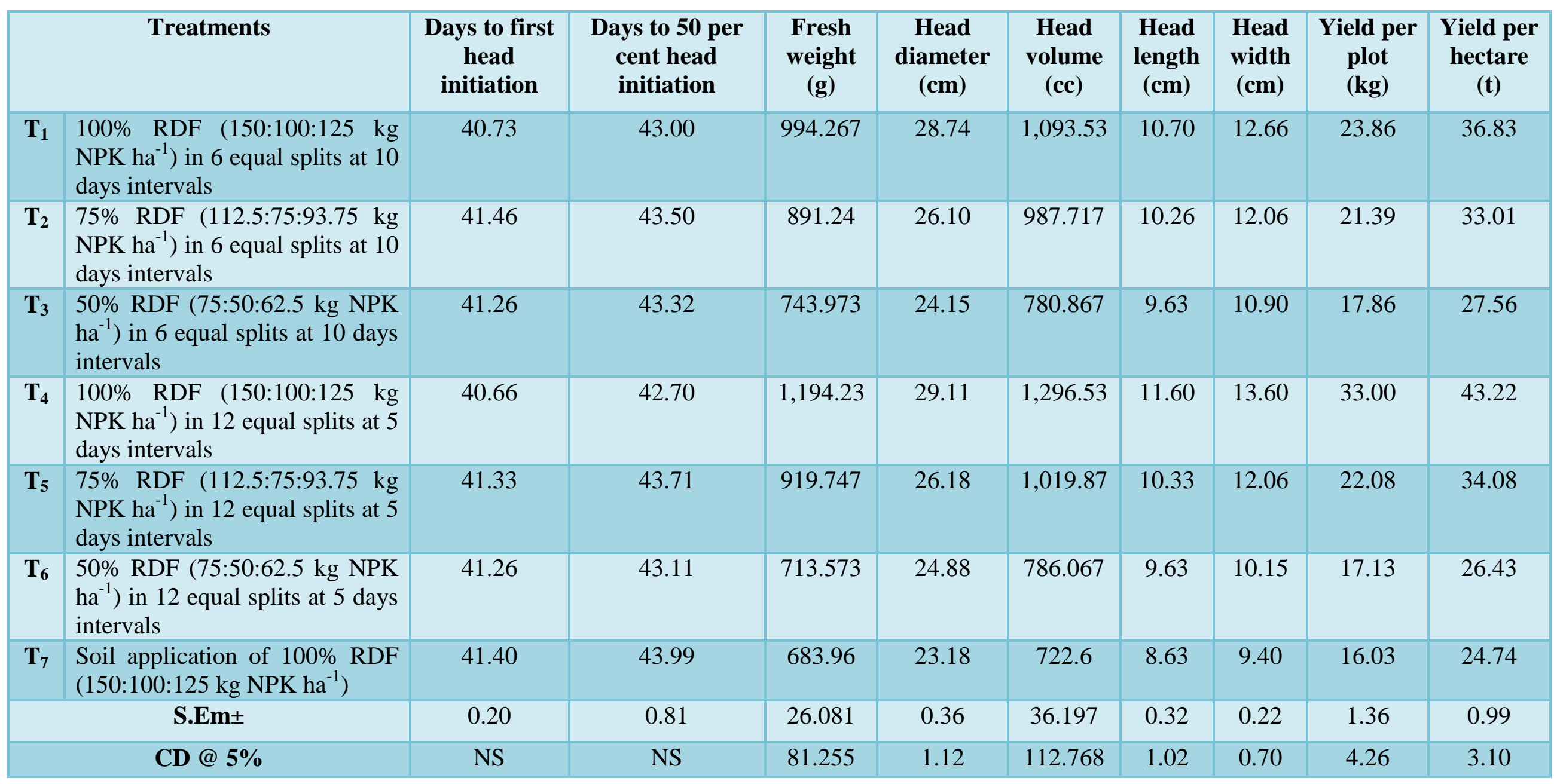


These results are in confirmity with the findings of Shinde et al., (2006) and Tanpure et al., (2007), Imtiyaz et al., (1999), Kumar and Sahu (2013), Verma et al., (2014), Kumari et al., (2015) and Mankar et al., (2015). An optimum nutrition levels might have provided better translocation of minerals and increased accumulation of photosynthates in plants thus increased head weight. The findings of this investigation were in close conformity with those of Wange et al., (1995), Chattoo et al., (1997) and Mohapatra et al., (2013).

The head diameter of cabbage is a vital parameter which influences the head size and its market value (Table 2). A larger diameter of head fetches better market quality of cabbage as well as processing. An application of $100 \%$ RDF (150:100:125 kg NPK ha ${ }^{-1}$ ) in 12 equal splits at 5 days intervals resulted in higher head diameter $(29.11 \mathrm{~cm})$ followed by $100 \%$ RDF in 6 equal splits (150:100:125 kg NPK ha $\left.{ }^{-1}\right)$ at 10 days intervals with $(28.73$ $\mathrm{cm})$. The higher values for diameter of head with these levels and combinations might be due to higher uptake of nutrients. These results are in conformity with the findings of Sharma et al., (2004), Shinde et al., (2006) and Tanpure et al., (2007).

The head volume was influenced significantly due to different fertigation levels (Table 2). A significantly higher head volume $(1,296.53$ cc) was observed in application of $100 \%$ RDF (150:100:125 kg NPK ha ${ }^{-1}$ ) in 12 equal splits at 5 days intervals. While, the minimum head volume $(722.6 \mathrm{cc})$ was observed with Soil application of $100 \%$ RDF. Head volume is positively correlated with yield. Significant variation in the head volume might be due to the variations in head length and head width. An increased head volume might be due to increased nutrient availability in the root zone leads greater absorption of nutrients by plants which caused more head weight. These results are in conformity with the findings of Shinde et al., (2006) and Tanpure et al., (2007), Imtiyaz et al., (1999), Kumar and Sahu (2013), Verma et al., (2014), Kumari et al., (2015) and Mankar et al., (2015).

The head length and head width were influenced significantly due to different fertigation levels (Table 2). Fertigation of 100 \% RDF (150:100:125 kg NPK ha ${ }^{-1}$ ) in 12 equal splits at 5 days intervals registered significantly higher head width $(11.60 \mathrm{~cm})$ and core width $(4.88 \mathrm{~cm})$ than rest of the fertigation treatments. The minimum head length of $8.63 \mathrm{~cm}$ and head width of $9.40 \mathrm{~cm}$ was observed due to soil application of $100 \%$ RDF. The maximum head length and width may be due to increased nutrient availability in the root zone leads to greater absorption of nutrients by plants which might increased the vegetative growth and more translocation of photosynthates towards head which increased head length. These results are in conformity with the findings of Sharma et al., (2004), Shinde et al., (2006) and Tanpure et al., (2007). Verma et al., (2014), Verma and Nawange (2015) in cabbage and Prasad et al., (2009) in Chinese cabbage, Hossain et al., (2011).

The cabbage yield was influenced significantly due to different fertigation levels (Table 2). Fertigation of $100 \%$ RDF (150:100:125 kg NPK ha ${ }^{-1}$ ) in 12 equal splits at 5 days intervals registered significantly higher cabbage yield per plot $(33.00 \mathrm{~kg})$ and yield per hectare $\left(43.22 \mathrm{t} \mathrm{ha}^{-1}\right)$ than rest of the fertigation levels. However, minimum yield per hectare was recorded in $\mathrm{T}_{7}$ (control). Yield is a complex character which involves the interaction of several intrinsic and external factors. It largely depends upon the production and mobilization of carbohydrates, uptake of water and nutrients from the soil, in addition to several environmental factors to which plants is exposed during the growing 
period. At higher dose of fertigation level, crop might meet out its nutritional requirement at respective growth stages leads to luxurious growth resulted in more interception of light and more translocation of photosynthates from source (vegetative part) to sink (reproductive part) which enhanced the yield. These results are in agreement with those reported by Shinde et al., (2006) and Tanpure et al., (2007).

From the present investigation, it can be concluded that application of $100 \% \mathrm{RDF}$ (150:100:125 kg NPK ha ${ }^{-1}$ ) in 12 and 6 equal splits at 5 and 10 days intervals through drip irrigation with water soluble fertilizes is ideal to achieve maximum growth and yield in cabbage.

\section{References}

Anonymous, 2016, Indian Horticulture Database, National Horticulture Board. Government of India. www.nhb.gov.in.

Anonymous, 2018, Indian Horticulture Database, National Horticulture Board. Government of India. www.nhb.gov.in.

Chattoo, M. A., Gandroo, M.Y. and Zarger, M.Y., 1997, Effect of Azospirillium and Azotobacter on growth, yield and quality of knol-khol (Brassica oleracea var. gongylodes L). Veg. Sci., 34(1): 1619 (1997).

Hegazi, H. H. and ALSadon, A. A., 2001, Water and nitrogen use efficiencies for broccoli and cauliflower under drip and furrow irrigation systems in Saudi. J. of Advan. Int. Agri. Res., (2): 55-75.

Hossain, D., Haque, Ashraful, Md., Abuyusuf, M., Riad, M. M. and Hussain Iqbal, A .S. M., 2011, Response of cabbage to different levels of fertilizer application in salna silty clay loam soil. Bangladesh Res. Pub. J., 6(2): 155-166.

Imtiyaz, M., Mgadla, N. P. and Manase, S. K., 1999, Drip irrigation scheduling for cabbage under semi-arid climate. Trop. Agril., 78(2): 99-103.

Kadam, U. S., Deshmukh, M. R., Takte, R. L. and Daunal Engd, V. P., 2006, Fertigation management in cauliflower. J. Maharashtra Agric. Univ., 31(3): 252-255.

Kumar, P. and Sahu, R. L., 2013, Effect of irrigation and fertigation levels on cabbage. Asian. J. Soil Sci., 8 (2): 270274.

Kumari, C., Mankar, A., Karuna. K., Solanki, S. S. and Singh, V. K., 2015, Effect of different levels of nitrogen and microbial incoculants on yield and quality of cabbage. Indian J. Agri. Sci., 85(4): 515-518.

Mankar, A., Kumari, C. and Karuna, K., 2015, Effect of nitrogen levels and microbial inoculants on growth, yield and quality of cabbage. Prog. Hort., 47(2): 296-299.

Meena, M. L., Ram, R. B. and Singh, M. K., 2011, Effect of nitrogen, phosphorus and potassium on growth, yield and quality of cabbage (Brassica oleracea var capitata L.). Environ Ecol., 29(3): 1109-1111.

Mohapatra, S. K., Munsi, P. S. and Mohapatra, P. N., 2013, Effect of Integrated Nutrient Management on growth, yield and economics of broccoli (Brassica oleracea L. var. italic Plenck). Veg. Sci., 40(1): 69 -70.

Muhammad, D., Muhammad, Q. and M. Alam., 2007, Effect of different levels of $\mathrm{N}, \mathrm{P}$ and $\mathrm{K}$ on the growth and yield of cabbage. J. Agric. Res., 45 (2): 171178.

Panse, V. G. and Sukhatme, P. V., 1985, Statistical Methods for Agricultural Workers. Fourth Edition. ICAR Publication, New Delhi.

Parameshwara, G., 2003, Evaluation of cauliflower (Brassica oleracea var. botrytis L) hybrids with different levels 
of spacing under greenhouse and open condition. M. Sc. (Hort.) Thesis, Univ. Agri. Sic., Bengaluru.

Prasad, P. H., Bhunia, P., Naik, A. and Thapa, U., 2009, Response of nitrogen and phosphorus levels on the growth and yield of chinese cabbage (Brassica campestris L. var. pekinensis) in the gangetic plains of West Bengal. J. Crop and Weed, 5(2): 75-77.

Rakh, A. J., 1992, Efficiency of liquid fertilizer through drip and surface irrigation method in cabbage (Brassica oleraceae var. capitata L.) in Entisols. M.Sc. (Agri.) Thesis submitted to Mahatma Phule Krishi Vidyapeeth, Rahuri, Maharashtra.

Sanchita, B., Phookan, D. B., Kachari, M., Hazarika, T. K. and Das, K., 2004, Growth, yield and economics of broccoli under different levels of nitrogen fertigation. Hort. Sci., India. 67: 279-282.

Sharma, A., Kumar, R. and Rana, M. C., 2004, Effect of planting geometry and fertilizer levels on growth and yield of red cabbage under high hill dry temperate condition of North - Western Himalayas. Veg. Sci., 31(1): 92-94.

Shinde, P. P., Chavan, M. G. and Newase, V. B., 2006, Studies on fertigation in cabbage. J. Maharashtra Agric. Univ., Pune, India. 31(3): 255-257.

Singh, S. K., Singh, T., Singh, B. N. and Verma, R. B., 2004, Response of fertility levels and plant density on growth, yield and quality of hybrid cabbage. Veg. Sci., 31(1): 69-72.

Singh, R., Chaurasia, S. N. S. and Singh, S. N., 2006, Response of nutrient sources and spacing on growth and yield of broccoli (Brassica oleracea var. italica Plenck). Veg. Sci., 33 (2): 198-200.

Tanpure, S. N., Patil, P. V., Pingale, L.V., Gutal, G. B. and Bote, N. L., 2007, Effect of different levels of fertilizer application on yield of cabbage. $J$. Maharashtra Agric. Univ., 32(1): 151152.

Thompson, T. L., Doerge, T. A. and Godin, R. E., 2002, subsurface drip irrigation and fertigation of broccoli: Yield, quality and nitrogen uptake. Soil Sci. Soc. American J., 66:186-192.

Verma, H. and Nawange, D. D., 2015, Effect of different levels of nitrogen and sulphur on the growth, yield and quality of cabbage (Brassica oleracea L. var. capitata). Agric. Sci. Digest., 35(2): 152154.

Verma, R., Maurya, B. R. and Meena, V. S., 2014, Integrated effect of bio-organics with chemical fertilizer on growth, yield and quality of cabbage (Brassica oleracea var. capitata). Indian J. Agril. Sci., 84(8): 914-919.

Wange, S. S., Patil, P. L., Mehar, B. B. and Karkeli, M. S., 1995, Response of cabbage to microbial inoculants and increasing levels of nitrogen. $J$. Maharashtra. Agri. Univ., 20(3): 429430.

\section{How to cite this article:}

Mohammadullah Nikzad, J. S. Aravinda Kumar, M. Anjanappa, H. Amarananjundeswara, B. N. Dhananjaya and Basavaraj, G. 2020. Effect of Fertigation, Levels on Growth and Yield of Cabbage (Brassica oleracea L. var. capitata). Int.J.Curr.Microbiol.App.Sci. 9(01): 1240-1247. doi: https://doi.org/10.20546/ijcmas.2020.901.137 